\title{
III. 関連する医学・医療分野の歴史
}

\section{3. 内視鏡技法（治療を中心に）}

\section{丹羽 寛文}

Key words：高周波電流, ポリペクトミー, 内視鏡的止血, 粘膜切除, 腹腔鏡下手術

\section{1. 初期の内視鏡的治療}

耳兽咽喉科, 泌尿器科領域では早くから直達 鏡直視下にポリープを切除する方法が試みられ ていた.しかし消化管を中心とした内科領域で, 内視鏡を利用した治療が始められたのは比較的 新しく, 昭和 40 年代の始め頃からである.この 頃になるとファイバースコープも実用になり， 直視下生検が可能となって，生検鉗子口を利用 して内視鏡直視下の治療が試みられる様になっ た.

最も初期の内視鏡治療としては，常岡ら ${ }^{1,2)}$

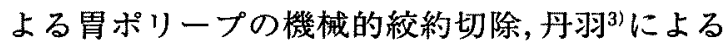
高周波電流を用いた胃ポリープの焼灼摘除，並 木らによる胃壁内局所注射を用いた潰瘍治療な どがある. 常岡らの方法は, ポリープの基部を 鋼線で機械的にくびり切り摘除回収を図るもの で, 昭和 43 年（1968 年）第 65 回日本内科学会 におけるシンポジウム“早期胃澏の内視鏡，（1） 現況と将来”で発表された。また丹羽による高 周波電流の応用は同じく昭和 43 年秋の第 6 回日 本内視鏡学会, 第 10 回日本消化器病学会合同秋

にわひろふみ：聖マリアンナ医科大学
季大会シンポジウム“消化管の生検”において 発表された。並木らによる直視下注射療法は, 特殊な注射針をファイバースコープの錳子ロを 通して挿入し，難治性潰瘍の固い辺縁部にステ ロイドを局注し，この部を軟化させ潰瘍の治套 を促すものであった（1970）。

高周波電流の応用並びに局所注射法は，その 後の各種内梘鏡的治療の基本的手技となったも のである.

\section{2. 高周波電流導入のいきさつ}

内視鏡直視下に高周波電流を利用して，種々 の治療操作を行うことは，今日広く行われてい るが, その端初になったのが, 筆者の発表であっ た.このシンポジウムで筆者は高周波電流を応 用した生検ならびに胃ポリープの焼灼摘除につ いて報告し，内視鏡直視下の治療の可能性を述 べ，将来の発展を期待した報告を行った．まず この発表での高周波電流導入のいきさつを述べ てみたい.

筆者が高周波電流を導入したのは，早期胃癌 に対する生検への応用を考えたからである。生 検を可能としたファイバースコープの市販は, 昭和 40 年 (1965) 町田製作所, 昭和 41 年 (1966) 
オリンパス社からそれぞれ最初の機種が発売さ れて以来で, その後スコープの改良が行われる とともに直視下生検は急速に普及し，筆者の発 表当時は, 早期胃癌の診断に直視下生検が決め 手となることが明らかにされ，各施設から相次 いでその成績が発表された．しかしその一方生 検が広く実施されると共に，生検に伴う癌細胞 の深部への散布・浸潤さらに転移の誘発などが 䋰念され始めた. その後の検討でこの様な危惧 はないことが明らかになったものの, 当時はか なり心配されたものである，筆者は生検に伴う この様な危険があるならば，その防止をどの様 に図るか考慮し，高周波電流に上る組織採取法 を考案したわけである。これによれば組織採取 と共に鉗子先端の周辺の組織は変性凝固し, 癌 細胞の散布，転移は起こり得ないと考えた。

最初試みた方法は, 昭和 43 年 (1968) 夏であっ たが、テフロン被覆を加え絶縁した通常の生検 錐子を用い，組織をくわえ込んでから，高周波 電流を通し組織を採取する方法であった。すな わち機械的に刃で組織を切り取るのではなく， 高周波電流を用いて組織を切離した。これによ れば，鉗子杯中に組織が採取されるとともに， 鉗子先端周辺の組織は変性凝固し, 粘膜筋板以 下まで組織が切り取られても，癌細胞の深部人 の散布浸潤は起こり得ないと考えた。なお電流 は鉗子から外部に流れ, 通電時間も短いので, 鉗子杯中に採取された組織片には多少の変性が 加わっても組織学的検討は十分可能と想定した. 事実組織学的検討は可能であった. その後通常 の鉗子生検に伴う癌細胞の散布, 転移は杞憂に 過ぎないことが判明し，この方法自体直接の発 展はなかったが，その後まったく別個に現在大 腸の小ポリープに対し，組織を採取するととも に凝固破壊するhot biopsyが導入されている.

なお同じこのシンポジウムにおいて筆者は胃 ポリープの高周波電流による焼灼，凝固による 摘除について発表した。研究の初期には, テフ ロン被覆を施した太い鋼線を導子として鉜子ロ
から挿入し，先端金属部をポリープ茎にあてて 焼灼切断を試みた. 当初は先端金属部を長くし， 通常の電気メスを使用するごとく荎の切断を意 図したが，この操作がかなりむずかしかったの で，ポリープ頭部に導子先端を当て凝固する方 法に変更し検討した。しかし導子光端の固定が 不可能で，導子のあたる範囲も小さく，焼灼部 分が狭いという問題があった. そのためその後 は通常の生検鉗子にテフロン被覆を施し,ポリー プ頭部の一部をくわえその部を凝固させ，この 操作を繰り返してポリーブの脱落を図った。ポ リープが脱落するほど強く焼灼しなくても，凝 固が十分であれば，その後消化作用も加わって ポリープは自然に脱落し摘除が可能であった。

このシンポジウムの司会を担当された松永教授 から「将来の夢を語ってもらった」との評をい ただいたが，今日の内視鏡的治療の発展をみる と感慨深いものがある.

\section{3. ポリペクトミー術式の完成}

常岡らの機械的ポリペクトミーの報告を知っ たのち，筆者は生検鉗子を利用した導子を，ワ イヤーループ式にかえ，ポリープの高周波電流 による摘除回収を試み，翌昭和 44 年 11 月の第 8 回日本内視鏡学会関東地方会において報告し た4．またこのさいポリープの切断回収の容易さ を計るため, 2 本の鉗子挿入が可能な 2 チャンネ ル式ファイバースコープを試作し発表した。 ち なみにこれは, 2 チャンネル式ファイバースコー プの最初の報告でもある.しかしこのファイバー スコープは視野角が狭く, 鉗子起上装㯰も無く, 2 本の鉗子あるいは導子を別個に操作するのが難 かしかった．その後 2 チャンネルファイバース コープは逐次改良され市販され，ポリープの切 断回収は極めて容易となった. もっとも現在で は 2 チャンネルファイバースコープを用いずと も, 通常のファバースコーブあるいは電子スコー プでも機器の発展, 技術の進歩により, ポリー 
プの切除回収は容易に行える様になった．さて 筆者が高周波電流を応用して胃ポリープの摘除 を始めたのは昭和 43 年であったが, 同年秋より 東大紛争が激化し，筆者らの研究室もバリケー ドで封鎖され, 研究活動はまったく不可能となっ た.さらに当時の東大病院中央手術部部長より, 中央手術室を内科が使用することも禁じられて しまった.したがって筆者自身はポリペクトミー についてその後の検討が出来なくなってしまっ た。しかし筆者の発表後しばらく間をおいて， 他の施設でも高周波電流によるポリペクトーの 報告が相次いで行われた(河内ら5)，1971；大木 $ら^{6)}, 1972$; 中村 $5^{7)}, 1972$; 森ら $\left.{ }^{8)}, 1972\right)$ 。ま た胃ポリープのみならず，大腸ポリープにも， ポリペクトミーが広く応用される様になった。

\section{4. その後の内視鏡的治療法の発展}

さらに高周波電流の応用は粘膜下腫瘍の診断 に対し，表面を覆う粘膜をカットし生検を行う 方法 (倉俣ら $\left.{ }^{9)}, 1972\right)$ ，出血時の露出血管に対 して焼灼止血する方法 (平塚ら ${ }^{10}$ ， 1971，竹本ら， 1972）などにも拡げられた，高周波電流を用い た組織の切開は,さらにパピロトミー(川井ら ${ }^{11)}$, 1973 ；相馬ら ${ }^{12) ， 1974 ; C l a s s e n, ~ 1974 ） な と ゙ に も ~}$ 応用されるようになった。

その他内視鏡を用いた治療法としては凍結療 法(城所, 1975), ポリープの薬棛による凝固な どの試みも報告されている.

\section{5. 各種の止血法}

さらに実験的胃びらんに対する硬性鏡と $\mathrm{CO}_{2}$ レーザーによるGoodaleら $(1970)^{13)}$ の報告を噙矢 として, Argonレーザーを臨床例に応用したFrühmorgenら (1976) ${ }^{14)}$, さらにNd:YAGレーザー によるKiefhaberら (1977) ${ }^{15)}$, その他竹本 - 小黒 らによりレーザによる止血法が検討され実用化 が図られた．消化管出血に対する内視鏡的治療
には，その他クリップによる林(1975)，倉俣ら の方法, 浅木による純エ夕ノール注射法 ${ }^{16)}$, 田 伏 ${ }^{17)}$, 村島らによるマイクロ波凝固法, Protell $ら^{18)}$ によるヒートプローブ法の開発導入などがあ る.

\section{6. その他の内視鏡的治療}

その他食道静脈瘤に対し凝固剂を注入し，こ の部を固める内視鏡的食道静脈瘤硬化療法, 内 視鏡的食道静脈瘤結禁術等が実用化され, 現在 広く行われている ${ }^{19}$. さららに切除不能進行食道 癌，噴門癌で狭窄を来した場合，狭窄に対する 对策としてプロテーゼを挿入し通過を図る方法 $\left(\right.$ Tytgat $\left.1980^{20)}\right)$, 膵・胆道癌での狭窄に対しス テントの挿入 (中沢, 山川ら), 内視鏡的に胃瘦 を造設し栄盖管理を行う方法（Gaudererら $\left.1980^{21}\right)$ 等々内視鏡を利用した治療は現在多種多 様のものが開発され，広く普及を見る様になっ た.

\section{7. 早期胃癌に対する粘膜切除}

とくに早期胃癌，大腸癌に対しては，外科手 術に代わって内視鏡直視下の切除が広く行われ る様になり,隆起形成型に対するポリペクトミー のみでなく，胃および大腸の表面型，平坦型の 早期癌に対しても, 粘膜下に生食水あるいは各 種の薬液を注入して人工的に隆起を形成させ, ポリペクトミーと同様の手技で切除する方法 ${ }^{222}$ が いわゆるストリップバイオプシー23)あるいは高張 Na-epinephrine液局注併用切除 $\left(\mathrm{ERHSE}^{24)}\right)$ と して一般化している. 勿論食道の早期癌に対し ても内視鏡的粘膜切除は現在広く行われ，その 適応を巡っての論議が活発に行われている. 早 期胃癌に対する内視鏡的治療としては，内視鏡 的切除法以外にも組織破壊（非切除）による方 法として, laser (Nd: YAG laser, PDT, laserthermia) ${ }^{25)}$, micro wave heater probe ${ }^{26)}$, 5- 
表，早期胃癌内視鏡治療の道応

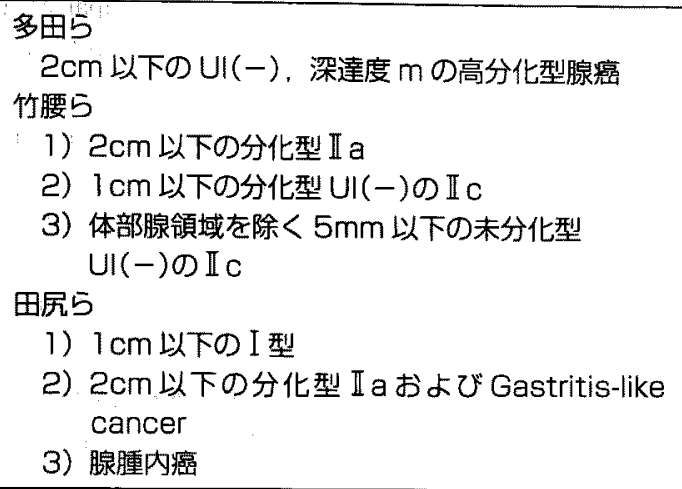

FU，MMCなどの薬剤注入による治療なども症 例に応じて行われている．早期胃癌の内視鏡的 治療の適応としては，現在表に示すものではり ンパ節転移がないことが明らかにされており， この範疇のものが内視鏡的治療の適応とされて いるが，適応拡大を巡っては諸施設でさらに検 討が進められている．また超音波内視鏡による リンパ節転移の診断の検討等もあって，転移り ンパ節に対する抗癌剂局注の試みなども模索さ れている.これらが実用化されることで早期癌 の内視鏡的治療の適応が一層拡がることが期待 される．なお進行癌に対するレーザ一温熱療法 も試みられている(田尻 1986) ${ }^{27)}$.

\section{8. 腹腔鏡下手術}

さらに近年脚光を浴びているものに，腹腔鏡 下手術による非開腹的手術がある。この方法は 硬性鏡を使用した腹腔鏡観察下に，腹壁にあけ た小切開を通じて鉜子を挿入し，遠隔操作で手 術操作を行うものである．腹腔鏡手術は当初胆 震摘出術に応用され28-30)，本邦でも1990年以降 胆䨳摘出術の定型的手技として認められる様に なった ${ }^{30)}$. 最近では手技の一層の拡大が試みら れ，総胆管結石の治療も行われている。本法の 評価が高いのは，開腹術と同様の根治的治療手 技であり，かつ患者に与える侵熟が少なく，入
院期間が短縮出来，術後の瘾着によるイレウス の危険が少なく，美容上の利点もあって，患者 のquality of lifeに㟢与する所大なる為である.近 年さらに適応が広げられ，虫垂切除術，胃，十 二指腸潰瘍穿孔に対する閉鎖術，胃，大腸癌な どに対する切除術などにも行われ，従来の外科 手術がまったく一変する傾向にある ${ }^{30)}$.

終りに

とくに内視鏡が電子スコープとなった現在, 同一画面を同時に多人数で観察できる様になっ て，共同作業はますます実施しやすく，内視鏡 下の治療は今後ますます盛んになる傾向があり， 治療内視鏡学として内視鏡学の大きい部門を占 めるにいたっている．好むと好まざるとにかか わらず，内視鏡的治療は将来共一層の発展を来 すことが期待されている。

\section{文献}

1）常岡健二：早期胃癌の内視鏡. 日内会誌 $57: 1173,968$.

2）常岡健二,内田隆也：われわれの考案した内視鏡下の胃 ポリープ切断採取法一ポリープ切断器および採取器につ いてー. Gastroenterol Endosc 11:174-184, 1969.

3）丹羽寛文：生検用ファイバースコープの改良ならぴにカ ラーテレビジョンおよび高周波電流の生検への応用.Gastroenterol Endocs 10:315, 1968 ; 同題. 日消会誌 66 : 503-504, 1969.

4）丹羽寛文：第 8 回日本内視鏡学会関東地方会追加口演. Gastronterol Endosc $11: 437,1969$.

5）河内秀希，他：胃疾患の局所療法（その3）一胃ポリー プ. Gastroenterol Endosc 13:296-297, 1971.

6）大木一郎, 他：高周波電流によるポリープの除去. Prog Dig Endosc 1:80-83, 1972.

7）中村光司, 他：高周波電流によるポリープの除去. Prog Dig Endosc 1:77-79, 1972

8）森 武生,新藤 光：Transendoscopic polypectomyの経 駼. Prog Dig Endosc 1:84-86, 1972.

9）合俣英夫，他：胃粘膜下腫演の生検診断（TGF-S Olympus処置用ファイバースコープの経験例)について.Prog Dig Endosc 1:27-29, 1972.

10）平塚秀雄：出血胃潰瘍の内視鏡診断と治療. Gastroenterol Endosc 13:107-110, 1971. 
11) Kawai, et al : Preliminary report on endoscopical papilotomy, J Kyoto Pref Univ Med 82 : 353-355, 1973.

12）相馬 智, 他：内視鏡的乳頭括約笳切開術および遺残. 結石摘出の試み一第 1 報Gastroenterol Endosc 16:446452, 1974.

13) Goodale RL, et al : Rapid endoscopic control of bleeding gastric erosions by laser radiation. Arch Surg 10:211-214. 1970.

14) Fruhmorgen $P$, et al : Endoscopic laser coagulation of bleeding gastrointestinal lesions with report of the first therapeutic application in man. Gastrointest Endosc 23: 73-75, 1976.

15) Kiefhaber $P$, et al : Endoscopic control of masive gastrointestinal hemorrhage by irradiation with a high-power Neodymium-YAG laser, Prog Surg 15 : 140-155, 1977.

16）浅木 茂,他：消化管出血に対する内視鏡的止血法の止 血機序とその位膡づけ. Gastroenterol Endosc $26: 2279$ 2284,1984 .

17）田伏克惊, 他：内視鏡的マイク口波凝固止血法. Gastroenterol Endosc 24:1526-1535, 1982.

18) Protell RL, et al: A new endoscopic thermal cautery which stops experimental bleeding safely, Gastroenterology $78: 1239,1980$.

19）食道静脈瘤硬化療法研究会：昭和 61 年度食道静脈瘤硬化 療法に関するアンケート調査報告. 1-14, 1986.

20) Tytgat GN : Endoscopic methods of treatment of gastrointestinal and biliary stenosis. Endoscopy 12 (Suppl.)
$57-68,1980$.

21) Gauderer NML, et al : Gastrostomy without laparotomy: a percutaneous endoscopic technique. J Pediatr Surg 15: $872-875,1980$.

22) Deyhle $P$, et al: A method for endoscopic electroresection of sessile colonic polyps, Endoscopy $5: 38-40,1973$.

23）多田正弘, 他：Strip biopsyによる治療. 外科診療 27： 1849-1856, 1985.

24）平尾雅紀，他：胃の腫瑒性病変に対する内視鏡的除法. Gastroenterol Endosc 25:1942-1953, 1983.

25）田尻久壅：早期胃癌に対するレーザー内視鏡治療一接触 照射法と非接触照射法の特徵. 日本レーザー医学雑誌 $11: 41-44,1990$

26）永井祐吾：早期胃癌に対する内視鏡的マイクロ波凝固療 法の局所根治性に関する研究. Gastroenterol Endosc 29: 2153-2165, 1987.

27）田尻久雄, 他：光化学療法および局所温熱療法の検討一 実験的研究を含めて. Gastroenterol Endosc 28:22822288, 1986

28) Perissat J, et al:Gallstone ; Laparoscopic treatment cholecystectomy, cholecystostomy and lithotripsy. Surg Endosc $4: 1-5,1990$.

29) Cuschieri A:Editorial laparoscopic cholecystectomy. Am J Surg $159: 273,1990$.

30）丹羽䁇文：消化器内視鏡治療の実際 日本メディカルセ ンター, 東京, 1992. 